\title{
The Civilizational Project and Its Discontents: Toward a Viable Global Market Society?*
}

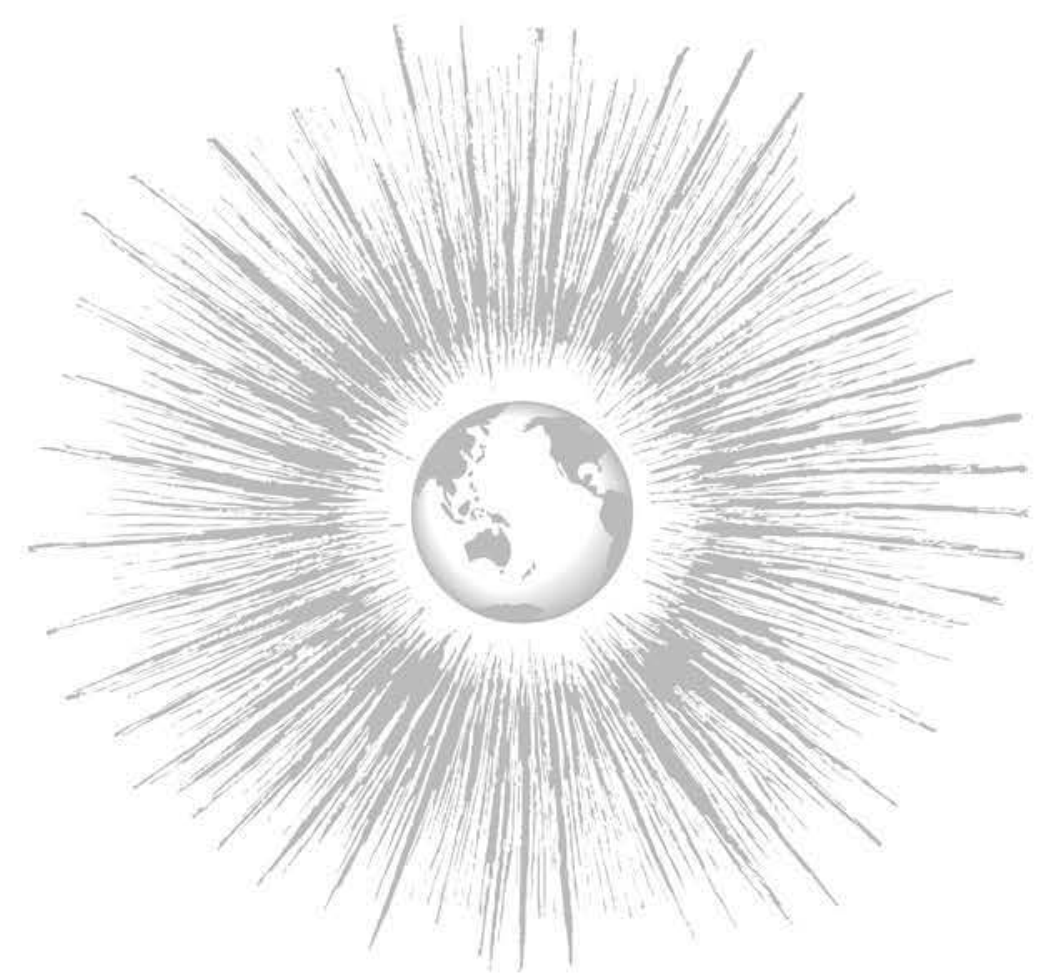

Volker Bornschier

PREFACE

I agree with the point of an anonymous reviewer arguing that a profound discussion on the prerequisites of a viable global market society has too many facets to be contained within the bounds of a single journal article. Yet, in order to enter the debate now we should not wait until book length treatments become available - often only after years. This is, therfore, an essay attempting to overview various conflicts and contradictions within the global social system. It sythesizes arguments developed in more detail elsewhere.

\section{THE GLOBALIZATION OF MARKET SOCIETY}

History has accelerated enormously since the 1980 s; world society has changed so dramatically in various respects that references to the end of the postwar era now actually make sense. The historical turning point was 1989-91, when the competition between systems ended with the victory of capitalist market society over its biggest challenger since the industrial revolution, real existing socialism. Now that the historic rival has been driven from the field of battle, no other sociopolitically relevant alternative exists; capitalist market society is now the sole voice promising progress and the improvement of life circumstances. This type of contemporary diagnosis led to the problematic discussion of the "end of history" In contrast, other inter-

* The copyright of this essay is held by the author. An earlier German version appeared in 1997 in the volume Frieden machen, edited by Dieter Senghaas (Frankfurt am Main: Suhrkamp, 1997). I would like to thank Richard Schauffler for his valuable help on this English edition of the essay and an anonymous reviewer for his or her thoughtful comments.

JOURNAL OF WORLD-SYSTEMS RESEARCH, $V, 2$, SUMMER 1999, I65-I85 htep://jwstuctedu/ 
preters paint the frightening picture of intensified cultural conflict, which is supposed to replace the old East-West confrontation.

Since at least the time of the aforementioned historic change, the success of market society and the growing realization of the fragility of the global ecosystem are two phenomena that can be accurately referred to with the catchword "globalization." With the disintegration of the state socialist counter-core, market society truly becomes hegemonic. The wave of democratization also contributes to the proliferation of the second key institution of the modern age, democracy, amplifying it to an extent never before achieved. However, we must ask whether globalization - understood as the spread of originally Western institutional practices to further parts of the globe - signifies progress for the civilizational project.

The fact that new ethnonational and religious fundamentalist movements —often interpreted as new "antimodern" movements — encompass large parts of the globe derives from reasons discernable by social science, reasons older than this historical turning point, but nonetheless connected to it. Socialism was not only the principal challenge to capitalism since industrialization, it also — and this may sound provocative-facilitated the path into the modern age: Marx's theory of history could integrate anti-modernist currents because capitalism was regarded as a necessary way station on the road to communism. Class struggles were regarded as accelerators of the development of capitalist market society, a modern society whose imperfect form was to be finally surpassed by a classless communist society.

Thus, in the world society of the postwar era, the East-West contradiction also had integrating effects. Strategic groups in the periphery could connect their belief in modernization with anticapitalist and anti-imperialist positions. This was possible because socialism promised to overcome the imperfect form of the modern age; thus, both modernization and anticapitalism could be connected without contradiction. Contradictions between interests could be expressed in class terms in the Marxist sense without calling the modern age as such fully into question.

With the dissolution of real existing socialism at the beginning of the 1980s, and its subsequent collapse at the end of that decade, this linkage collapsed. As a result, ethnically and religiously constructed lines of demarcation between groups fighting for power have become even more important.
Whether they remain so in the long run depends on some issues that are important to discuss.

The ethnicization of the articulation of conflict seems therefore less a sign of the weakness of the modern age than its - yet incomplete-accomplishment, which is achieved through thrusts in certain phases. The antimodern reactions against the contemporary thrust are so severe precisely because the modern does not even modernize itself, that is, it does not develop according to its own immanent principles. For the present moment, doubts may arise as to the contribution of the market society to the advance of the civilizational project. These are justifiable as long as market society does not succeed in broadening its basis of legitimation. The deficiencies of the present form of market society and the opportunity for their elimination and the expansion of its basis of legitimation - without which a peaceful future has little chance-is the focal point of the discussion in Section I. In the remainder of the essay we address known but also new sources of conflict that must be evaluated and taken into account in any discussion of the civilizational project. These include the structural change of the core, with which major threats to peace were connected in the past (Section II); the previous obstructions to, but also the new possibilities for, catch-up development (Section III); finally, we discuss new forms of conflict beyond the world of nation-states (Section IV).

\section{A Broader Foundation for the Legitimation of Market Society}

The question of whether market society - which up to now has hardly succeeded in establishing its merits outside the core, that is, the OECD countries - can find the resources to combat the global decline in prosperity and threats to the environment is an important question when we look toward the future.

The debate about what the market can and cannot achieve has been uninterrupted ever since it was initiated at the beginning of the last century upon the initial expansion of the liberal project. Economic liberalism and its market credo, which historically became quite effective, has also been characterized by markedly ideological phases. These phases have been characterized by the fact that particularist interests lie hidden behind the pretext of universalist justifications, and the question of justice has either not been posed broadly enough, or the answer to this question has not been provided 
by mere operation of the market. The debate about what the market can and cannot achieve has been revived again following the problematic liberal fundamentalism of the 1980s. The economic doctrines that have been hegemonic since then place much greater trust in the self-regulating capacity of the market than the previously dominant doctrine of Keynesianism. However, this renaissance of the market necessitates a new reflection on how the basis of market society's legitimacy can be broadened, what the tasks of the state are, and how the interplay of market and states is to be regulated in world society.

In what follows, we suggest four forms of market failure in the spheres of economics and politics that should be addressed in any effort to broaden the foundation of market society. These include (1) environmental goods; (2) the point of departure for participants in the market; (3) the basic conditions of the market; and (4) the unregulated competition among governments. Without such an expansion, the civilization of world society will not take place.

\section{I.1 - The Market and Securing the Fundamental Basis of Life}

The environment itself sends out no market signals in form of prices and thus remains outside the calculations of market participants. The market is not a reflexive system that protects itself from its self-destructive consequences. Therefore, the actual and anticipated future costs for the avoidance of additional environmental damage and the elimination of existing environmental contamination must be introduced from outside the market itself. In this respect it is an aspect of security policy, because the achieved level of affluence is being endangered anew today. From the outset, the market as a creator of prosperity was the centerpiece of the legitimation of market society. In this regard, indisputable advances have also been achieved, last but not least in form of the increased democratization of affluence in mass consumption society, which admittedly is confined to the island of affluence of the OECD countries. For a long time, however, growing parts of the population have feared a loss of affluence for themselves and their descendants due to environmental pollution. The precise scope of these fears remains unknown. However, the absence of this knowledge is not decisive for a well-understood security policy; what is politically relevant is the insecurity itself.
The shift in thinking in the triangle of development, ecology, and market is a topic we have elaborated upon in other places. Here we shall make reference to the outcome of this long process. The concept of sustainable development represents a noteworthy rethinking of old ideas. Ecology and development converge toward sustainable development and are acted upon by the market economy, whose central measures consist of the internalization of environmental costs. In this way, the price of goods and services sends signals regarding their environmental compatibility. If ecological and economic objectives are no longer seen as contradictory opposites but rather coalesce in a synthesis that promotes harmony among members of society and between humankind and nature, then we are speaking of a revolution in economic doctrine that in this century has only one comparable antecedent - the Keynesian revolution. The latter was a pioneering effort at making social welfare, redistribution, and stable growth compatible, something that was beyond the realm of possibility according to the thinking of bourgeois economics at that time, but which nevertheless later programmatically unleashed the successful welfare state era of the highly developed world.

The new thinking on ecology and economics was not confined to Rio and international discourse. The White Paper of the European Union of 1993 acknowledges the new model and goes on to say that the scientific knowledge for a sustainable environmental policy has already been available for some time and only awaits its introduction within a new regulatory system for the economy. One reason for this is the fact that the ecological policy instruments of the market economy have not yet been seized by any interest group and are even less widely known among the broader population. In addition to transparency and credibility, new legislative measures under democratic conditions are needed, above all individual incentives for cooperation. For every business, as well as for every citizen, the immediate advantages must be sufficiently large. Furthermore, measures must address in a recognizable way the issue of prevention; environmental pollution is to be prevented through such measures, based on the principle that the party responsible is liable for the damages. Whoever damages the environment must bear the expense for their actions. In addition, these measures must be progressive; whoever limits environmental damages must be given further incentives to decrease the damages even more. 
In the atmosphere created by the Rio conference, it became possible for the first time to link environmental and development policy objectives in a new and plausible model. In this way, the interest of the South in a global ecology policy can be awakened and the mistrust directed at proposals in this area that was prevalent in the 1970 s can be overcome. Thus, a new moral basis for political demands regarding global redistribution became possible. The South's demand for redistribution, which had been legitimized in the 1970s by the historic condemnation of colonialization, found a new basis at the beginning of the 1990s. With the industrial development of the North, a large part of the common environmental capital has been exhausted, and therefore compensation for the South is only legitimate.

\section{I.2 - Markets and Justice}

Does a claim to social compensation exist outside of collective threats and the aforementioned political reason? Surely the rationale for a model of a socially and ecologically tenable market society is reasonable and just; however, it remains linked to a consensual evaluation of the global ecological threat. According to the dictates of political reason, the whole population must take part in the general social welfare, not simply those with large fortunes and those holding jobs. Otherwise, the resultant radical change would earlier or later spoil the happiness of the privileged. But, in order to raise the acceptance of the functional requirement to the level of an indisputable legal right a deep-seated rationale is required, one that follows logically from the construction of justice within market society itself.

Against the background of a bourgeois ethics that proceeds from the rights of the individual, in market society only those social differences that are created by the market are justified, that is, those that are based on individual differences in willingness and productivity. With the delegation of the majority of questions of distribution to the market that is typical for Western society, a weighty problem remains unsolved: the starting point for participants in the market is determined by factors other than the rationale of performance-based reward and optimal allocation of resources through the justice of the market. Here a question of justice arises precisely if, as is often the case, individuals encounter unequal starting points in terms of those resources upon which success in the market depends, and if this unequal opportunity is not based on individual choice and effort. Here formal education and vocational qualification as well as rights of ownership are particularly important.

In Western society this problem is being addresssed through compulsory schooling and its social magic of a zero hour-from which point on the progress of the students is only to be measured by their willingness and performance. The classic bourgeois justification of personal property as a natural right was delivered by John Locke, wherein he showed that work was the sole source and justification for personal property rights. The institution of inheritance as a source of property, through which approximately half of the property rights in Western society are actually acquired, stands in contrast to and outside a bourgeois rationale geared to individual performance, in so far as the latter requires equal opportunity at the starting point. However, a reformulation of the rationale of market society demands compensation for such unequal starting points on the basis of simple justice.

If market society is to be extended to the rest of the world, so that the latter can revive itself by means of this extension, compensation payments for unequal starting points must also be determined as a legal right, on which basis a social-liberal societal model can be erected. Such a legal right does not derive its rationale from disputable demands for redistribution, but rather from the framework of a bourgeois morality that requires the balancing out of unequal opportunities. In this way, the peacemaking project of a prudent world order based on balance contains a rationale that follows the logic of the construction of justice within market society.

\section{I.3 - Not Only the Half Modern}

The previous as well as the current decade were marked not only by upheavals but also by new beginnings. In the annals of world history this epoch will be recorded as the time that marked the democratic opening in the East and the South. This confirms the long ago overdue insight that democracy is not merely a supplement to prosperity but a complement of market society. Nevertheless, there are extremely important parts of the world in which autocratic political regimes not only defend but seek to justify themselves as unique paths to the modern age and reject demands for democracy and legal security (human rights) as interference of the Western core in the autonomous regulation of internal political affairs. 
This half-modern society (market economy, yes; democratic constitutional state, no) remains an alien element within the rationale of the market society. It narrows the legitimating foundation of the latter and shapes such half-modern societal arrangements into a possible threat to peace.

Economic freedom and political freedom form a tandem; the fact that they initially began to evolve at the same time was not an historical accident. This necessarily parallel design does not justify itself simply as a superior, affluence-creating power, but much more as a peacemaking form for the management of freedom and equal opportunity. The rationale for this will be briefly outlined. The very fact of political regulation on which market society necessarily depends simultaneously facilitates and impairs the taking of economic chances by active individuals, even when the rules are minimal. Even if these rules were to be strictly the same for everyone, and arranged in the form of a law-based state-something we assume here-they restrict the leeway, and therefore the freedom, of individuals differently. This restriction is in no way just when viewed in the context of freedom. In order to make freedom of action and political regulation compatible, the political rule-setting process must be established according to the principles of equal opportunity and individual freedom of choice. In this way, each individual has in principle the same chance with his/her vote to introduce personal preference into the political will formation. This is why the market and political democracy are inseparable as institutional solutions. The fact that this was not always the case even in what became contemporary core societies does not contradict this point. The absolutist and undemocratic arrangements were not successful in the long term when compared to the democratic project.

Should we not tolerate compromises with respect to democratic development in the context of the immense task of catch-up development today? Even the well-meaning despot himself, who is oriented toward the common good - and whose existence we hypothetically assume for purposes of discussion - is in no way legitimized and is therefore a threat to peace. He behaves like a rule-making and allegedly all-knowing director of a planned economy-he is an economist, because his rules influence the economic process. Moreover, since in the real world he would encounter more than merely minimal regulations, his possible wrong decisions would not be rectifiable. To be sure, he will seek to defend his actions in terms of the collec- tive welfare. However, in the context of the justice of the market, collective welfare is the result of decentralized decision-making. If this is true for the market, it must also be true for the institution that makes its rules. If, in the narrower sphere of the market, one bases the ultimate justification of legitimacy on autonomous individual decisions, so must it also be for rulemaking, without which the market cannot exist.

A half-modern - that is, a market society in combination with centrally planned rule-making, a path that the political rulers in societies like China want to pursue-does not provide a foundation that contributes to peace, no matter how economically successful such a path may appear to be at its inception. Peace can only be achieved by closing the loopholes in the system of justice. Political democracy and the constitutional state can only be disregarded at the expense of growing internal conflicts. In the interconnected world, such a development threatens peace.

The argument in this section should not be interpreted as speaking against macroeconomic planning but only against planning that is not democratically legitimized. Here we arrive at another problem that results from the economically motivated competition between different state regulations, a problem that admittedly would not be solved even if all governments were democratically established and effectively controlled by a constitution based on the rule of law.

\section{I.4 - Neither the Primacy of Economics nor the Supremacy of Politics}

The peculiarity of the world political economy lies in the criss-crossing relations between the economic sphere and the different political spheres, that is, the states. This is a result of the fact that the world economy is transnational, and has been long before we began to use the term globalization, although certainly it has become more distinctively so over the last quarter century. The regulatory frameworks of the individual states and groups of states are prerequisites that at first facilitate the competition and direct it along certain paths. Production, trade, and finance transactions are not without social prerequisites: protection is required; property rights must be acknowledged; people must be motivated to engage in exchange. The order created and administered by the state is by no means an incidental factor of production, but just as basic as labor, knowledge, organization, financial resources and credit. Governments, which are regarded as political under- 
takings, produce order as a public good and offer it to economic enterprises as well as citizens in the territory they rule. This is how governments influence the locational quality of their territory in the framework of the world economy.

States stand in a competitive relationship to each other not only in political-military terms, but, in the context of increasing economic globalization, also in terms of the "world market for social order." This not only because capital and labor can move among states, but also because varying degrees of long-term economic success are associated with different forms of social order. As a rule, governments are sensitive to this world market for social order. In order to hold their own, they are forced again and again to produce the social and political preconditions for economic success. If they fail to do so, or do so only insufficiently, they can neither achieve nor maintain core status in world society*

In principle, this competition among governments is to be assessed positively, like all other forms of economic competition. Through it, the institutions that provide for a compromise between capital accumulation and supply of goods and services on the one hand and legitimacy and claims on the other are selected out.

From this point it follows that it is valid to reconsider and develop new rules for the relationship of the market and politics — on the global, regional, and local levels. It would be incorrect to assume, however, that thereby the political sphere could assume primacy. It is surely correct to say that that when we talk about an established, "mature" market and its institutions we are talking about phenomena that are politically created and socially embedded, and in the final analysis beyond economics. But in a decentralized world, the politically created institutional arrangements stand in a competitive relationship to each other; for this reason, it is not merely the political logic of economic action but likewise the economic logic of political action that comes into play. This very fact places certain demands on the political praxis of regulation.

However, if state action is now recognized as a relevant economic good, which in a world of multiple states is subject to market forces because it is offered under conditions of competition, then likewise the basic condition of equal opportunity applies to this as well as every other market. Thus, unfair competition and dumping must be prevented; otherwise market failure occurs. This can be prevented by models of order for locational competition that link competition and cooperation. The tools for this are already known in principle and have been practiced for years in embryonic form in the interstate system - in the form of international agreements or so-called international regimes. The existing regimes and agreements have not yet grown to reflect the political consequences of globalization, however. In practice they produce no public goods for the world, because not all states are tied into the treaties. Even more importrant, up to now they have been restricted to single issues, resulting in conflicting aims and lack of effective links (e.g, trade and the environment). In the framework of world society, tied regimes that link political regulation with compensation to reversing the growing cleavage in well-being and promoting ecologically sustainable development are therefore both thinkable and desirable.

At the regional level, the European Union represents a more effectively positioned cooperation between nation-states, insofar as it goes far beyond a series of linked regimes. How is the remarkable new beginning of Europe to be classified? On the one hand, this exclusive regional cooperation infringes on laws against discrimination, for which the requisite international regulations now have to suffice. On the other hand, Europe has headed down an innovative path, and one that could serve as a model for the world. With this comment we now depart from our general treatment of aspects of market failure that must first be resolved to provide for peaceful resolution of conflict in the global market society, and move on to the transition of the core, which history teaches us has been ripe with conflict.

\section{II. - Structural Changes in the Core}

\section{II.1 - Europe's Path to the European Union}

Globalization and a tighter closing of ranks by the European states are only contradictory at first glance. The first implies a shift in power between the state and the economy in favor of the transnational economy, to which regional integration is an answer, a new deployment of an old weapon by the states. We have already spoken to important processes in this context. In the political world economy, first economic enterprises, and then states compete with one another. On the other hand, economic enterprises and states are dependent on each other. The supply of state-based order as a locational condition and the demand on the part of economic enterprises 
for the same must be united in practice. Here, negotiations are the typical form of exchange. As we have indicated elsewhere, the qualitative change of Western European integration in the first half of the 1980s was the result of one such round of negotiations.

The middle of the 1980s, during which the Single European Act accelerated the integration of Western Europe leapwise in the direction of political union - a process that took place after years of Eurosclerosis and which in its impact was only dimly perceived by most observers at the time-is readily explained: in the context of the fading lustre of the United States, the hegemon of the postwar era, and the continued economic ascent of Japan, the path toward political union represents Europe's attempt to remain a player in the post-hegemonic round of competition. This is something that is not necessary to account for here in detail, as there are unamibiguous indications of it in the official documents of the then Community. As early as 1982, one such document, in an argument repeated by the Commission in various forms, stated what is important: giving European businesses the certainty "that their activities will be able to develop in an economic unit similar in size to the American market and distinctly bigger than the Japanese market" (communication of the Commission to the Council).

With respect to the aforementioned desirable cooperation, which clearly must be aimed at a non-discriminatory framework, Western Europe's path to political union is not without problems. To be sure, the national orders of the fifteen member countries have been placed within a common framework that, however, erects a stronger border against the rest. This very fact is not altered by the itself defensive character of the integration impulse. In the words of Jacques Delors, the chief architect of the political character of integration, integration was about "rescuing Europe's future glory." In the same vein, at the beginning of the 1990s he urged that "the political project must move quickly, otherwise Europe will become an archaeological excavation site, where Americans and Japanese will come to look for lost modes of thought and lifestyles."

With the formation of the political union, the European state, which was the model for the world, departs from the national framework it originally helped to create. Concealed behind this move lies an innovation that could serve as a model for the world, and one that should not be underestimated. Since the first half of the 1980s, Western European integration moved toward the "outline" of a new type of state, one that represents an advance over the long and often strife-ridden European statebuilding. In contrast to the early history of the modern state (which was based on military expansion), here for the first time a large and economically potent structure was established through a "contract of association." This entity is a legal and economic community in which no member seeks to deprive any other of its cultural particularities. It is this characteristic, which is also reflected in the content of the social contract (which in fact is still being worked out) that holds the promise of a possible model for world society: the project is multinational and signals the end of the nation-state as the sole organization framework for social order. Indeed, it is reconciling the different manifestations of nationalism and liberalism in a multilevel system of governance. Moreover, the goal is convergence to limit prosperity differences among member states through supranational political regulation.

\section{2 - The Stabilization of World Peace without a New Hegemon}

To be sure, Western Europe's path to the Union is not only an innovation but also a geopolitical event that alters the constellation of power in the core, that is, the OECD countries. Only now, and after the elimination of the Soviet Union, is it possible to speak of a triad of comparably potent protagonists on the world stage: the USA, Japan, and Europe. However, according to cyclical interpretations of history, this would only represent a transitional stage in the competition for a new hegemonic leader.

The relative decline of US hegemony and the invigorated competition among the triad, forces which originally provided the impulse toward unification and to which the union itself now contributes, raises many questions about the prospects for world peace. Until now, in the opinion of several researchers, structural change at the international level has always been cycli$\mathrm{cal}$ and has taken the form of the rise and fall of hegemons, a process in which competition is considered especially threatening to world peace.

In this sense, many contemporaries ask, "Which member of the triad will win the race, that is, who becomes the next hegemon?" This question steers our thinking in the wrong direction, however. To be sure, at two points in the nineteenth and twentieth centuries hegemonic states were decisive in terms of the enforcement of a new hegemonic social praxis. These two cases, the English hegemony in the nineteenth century and the American after 1945, 
owe themselves to particular historic and systemic alignments of forces in the then core, conditions that are hardly likely to be repeated. According to cyclical theories, a necessary prerequisite for hegemony or world leadership is a very unequal distribution of resources among the competing states or groups of states. Three principal doubts arise with regard to the likelihood that such an unequal distribution will occur in foreseeable future:

(1) On the basis of past experiences one could argue that world war precipitated by hegemonic decline represents a mechanism which, through victory as well as defeat, could create again in the future very unequal strength among the powers in the core. Such a consideration misjudges the fact that systemic conditions have fundamentally changed. Today, all of the core powers engaged in economic competition are democracies. This is a completely new condition for the beginning of a new societal model. It is an observed regularity, or even perhaps a law of social science with no known exceptions, that democracies don't conduct war against each other;

(2) In the past, economic advantages could accumulate for a longer time in one society due to its superior social order, and could thereby produce considerable economic disequilibrium. This will hardly reoccur in the future due to globalization and democratization. Today societies learn very quickly from each other, because the competition between social orders is played out much more quickly, and successful arrangements in one country are copied or adapted more quickly by other countries;

(3) Earlier, the balance of power was an important means for setting limits on the ambitions of any one power to dominate others. In future, this mechanism will become even more effective. Western Europe's innovation within the triad consists of the fact that state power was organized by the fusion of different national states. As a result, Western Europe has risen to a stature of serious proportions in the triad and simultaneously effected a certain balance of the distribution of power in the OECD world.

Democratic market society, which for the first time reached truly global hegemony after the breakdown of the Soviet empire, will therefore not produce a new hegemon like Britain in the nineteenth century and the United States in the middle of the twentieth century. The rivalries within the
OECD world will not in fact vanish, but will be conducted on the economic terrain, and thus, formally speaking, in a peaceful manner. Whether or not this direction holds true for the entire world depends on the opportunities for catch-up development, which we address next.

\section{Beyond the Core}

\section{III.1 - Structural Changes in the Context of Catch-up Industrialization}

The revitalization of market society at the end of the East-West divide and the power shifts in the core have captivated contemporary observers until now. Structural changes in the system of development that have gradually developed in the postwar era likewise require reconsideration. Three challenging phenomena must be mentioned in this regard: (1) the continued marginalization of most of what was once referred to as the "Third World"; (2) the retrogressive development of the "Fourth World"; and (3) the ascending parts of the semiperiphery, from which already at least two states (South Korea-despite the present crisis, and Taiwan) have prepared to take on characteristics of core societies. In contrast to such exceptions, the majority of societies experienced the fate foretold decades ago by dependency theorists, even if the most dependent of them were not necessarily the worst cases.

How can stagnation, in most cases, and developmental dynamism in others be explained? Restrictions on the aforementioned competition of governments, through which the institutions that best mediate capital accumulation and the supply of goods along with legitimacy and claims are selected out, can provide an explanation. We can only touch lightly on the reasons why this mechanism, which obviously brought about the historic success of OECD capitalism characterized by the reciprocal linkage of capital and state as well as social balance in the core, did not for the most part function outside this domain. Rents from raw materials, from the exploitation of the East-West conflicts, and from compassion ("development aid" delivered into the hands of elites) permitted the power holders outside the core to remain a privileged and unproductive state class blocking the way towards catching up developmentally*

The hitherto exceptional success in late industrializing - the raw material deficient semiperiphery - shows that such roadblocks to development were absent: thus, important components of the dependency model were 
lacking. Yet, examples of successful late industrialization have remained exceptions in the postwar era as the dependency model predicted. In the future there are likely to be more positive cases, however, due to systemic change: the end of the East-West divide spells the cessation of rents drawn from threats to shift alliance. The new technological style leads into an information economy, one that reduces the strategic value of raw materials. The connected, intensified level of globalization leads to more competition for industry locations, areas whose competitive qualities must first be politically and socially created with corresponding institutional arrangements.

\section{III.2 - The Westernization of the World and Cultural Heritage}

In the future, when previous obstacles to development may become less relevant, two questions will become interesting: (1) Will the "West" remain western? (2) What consequences does competition have for the relationship between core culture and dissimilar cultures?

The cultural heritage of the Atlantic West has stamped the institutions that today undisputedly determine core status: the market in combination with measures of social balance, the law-based state with a political separation of powers and legal opposition, economic enterprises, and a credentialing system. That functionally equivalent, or even competitively superior, designs of the specifics of such central institutions are possible is demonstrated by the examples of successful catch-up industrialization, for which Japan after the postwar era was a model. In the Japanese case, cultural heritage was also important for successful catch-up industrialization. Along with a model of efficiency that relies less on individualism and more on groups, the following is also important: administrative and political elites that are not parasitic, but rather committed to the collective welfare and basic equality. For decades, these elites successfully guided capitalism with strategic planning that in fact did not hinder, but rather inspired. They are to be found in various countries in Asia, but are missing in Africa. Up to now, the majority of the Latin American countries have suffered from corruption and a perverse legacy of Western culture. After a decline that has thrown these countries back below previously attained levels of development, some now show signs of a hesitant resumption of the path to development.

Cultural heritage, which shapes modern institutions, can be a competitive factor that helps determine success and failure. When combined with modern institutions, it can achieve functionally equivalent - or even better - results than those rooted in the Atlantic West. For this reason, traditional modernization theory must be overhauled, and we can expect that in the future, core society will include more societies that do not belong to the Atlantic West.

Cultural heritage can also be a source of weakness for some societies in the competitive world-system, resulting in stagnation or even retrograde development. Even if we assume that competition will not have a culturally homogenizing effect, cultural elements that are not compatible with modern institutions will be pushed to the margins of world society. This fact can strengthen the ethnonational and religious fundamentalist movements we mentioned at the beginning of our analysis. And therein lies a source of conflict for numerous societies, one that will not disappear any time soon. The expansion of such conflicts and the threat to world peace that they represent will be exorcized, however, if and only if market society succeeds in reforming itself, and thereby creates an integrative, modernized modern age that becomes attractive to most inhabitants of the earth.

\section{Beyond the World of States: Thinking Globally and Acting Globally}

In response to globalization, we can recognize in the emerging formation not only new forms of the state but also the seeds of world civil society, which signify the transformation of global politics and are brought to life by the contradictions between political interests among transnational actors. In this way, politics becomes more complicated. Two very important transnational actors - economic enterprises and social movements - will be briefly discussed in the sections that follow.

\section{IV.1 - Transnational Enterprises}

The world-economic downswing since the late 1960s provided the impetus to extend the system of the transnational economy. In the mid1990 s, the system of the transnational economy consisted of about 45,000 headquarter firms that together controlled more than 280,000 subsidiaries abroad. A comparison with the circumstances of the second half of the 1960s makes the enormous increase clear. The globalization of capital natu- 
rally also had wider social consequences, in so far as it facilitated the tremendous growth of the group of the transnationally oriented professionals. In the transnational economy, the number of managers, lawyers, auditors, consultants - expanded to include design professionals (film, television, music, architecture and advertising) — has now risen into the millions.

A group of transnational protagonists that was still underrated until recently, one that thinks and acts globally like the transnational enterprises, has emerged from quite a different mold. Just like its established transnational counterparts, its prototypes and early manifestations of political opposition, protest, and civil disobedience can be found as early as the nineteenth century+

\section{IV.2 - Transnational Social Movements and Civil Disobedience}

It is not the optimization of economic rationality, but rather supralegal legitimation on the basis of human rights, that serves as the reference point for the political practice of civil disobedience. The Enlightenment is its deepest historical root; the bourgeois revolutions, as well as the central institutions of the modern age they brought into existence over a long period of time, owe their existence to civil disobedience. This has been made manifest in oppositional movements, in the representation of vital interests, and in the fight for recognition, to mention but a few examples.

According to the philosophy of natural rights, the individual, as the inalienable source of sovereignty, has a right to resist. The exercise of this right is not superceded by the social contract in instances in which appeal can be made to a supralegal moral value to which the state as agent of the social contract also remains bound. This is true not only in cases in which the contract can be improved by selective violation of laws, which are often subsequently rescinded in the name of progress, but precisely also in cases in which the contract is heretofore deficient, namely in global matters. In such situations, the practice of political opposition, protest, and civil disobedience has developed to become a social force beyond the market and the state. The partial violation of positive rights and the disruption of the everyday routines of social and political life (a process seen by many conformists as tiresome) are certainly only justified if the protagonists can plausibly appeal to human rights and the interests of humanity for support.
The transnational social movements are not the product of economic, but rather cultural, globalization, initiated by the expansion of education and changes in values. Since the anti-authoritarian student protests of the 1960 s, Western society has experienced an impulse toward the revolutionary modernization of its culture. Ascribed characteristics and group membership increasingly retreated in the face of a radical demand for the realization of the rights of the modern age. Freedom and self-realization, as well as the project of the individualization, were required. However, through this individualization, the way was cleared for seeing that which connects individuals in the end: the interests of humanity and a community of the human species. Thus, a wide array of social movements arose that not only transformed national politics; these transnational social movements grew to large numbers, and a critical "transnational civil society" established itself, one that began to introduce its concerns into world politics with some success.

Through their individual and collective actions, the protagonists of the transnational movements call for global responsibility for our common future and help build a bridge between the local and the global. Even if reform-oriented enterprises have begun to recognize a responsibility for solidarity with the whole world — at the Davos world economic forum in 1995 one repeatedly heard the phrase, "simply maximizing profits is not sufficient for the twenty-first century" - the transnational citizens movement is not coopted by this process. Like social movements in general, it is simultaneously characterized by its educational and oppositional character.

\section{IV.3 - Transnational Actors and the Transformation of Politics}

Transnational movements have gained stature and since the 1980 s have gone all out: with the questions that they put on the agenda of the world public, they place the entire planet squarely in view and challenge previous approaches to its problems. In the process they also strive for democratization and civilization and have as a model a global society of many options in a creative, polycentric world. Through their ability, proven in the practice, to not only address problems, but also to put oppositional points of view on the global agenda, they open a wide field for societal learning and set the course for the future. 
But the transnational citizen movements have become more than just signposts for the future. They are at the same time builders of a new institutional network for the rebuilding of society. They have assumed this position because they speak on behalf of the powerless; in addition to spectacular unconventional actions they rely on reason based on scientific expertise. These movements help to defend the dreams of the good life from the logic of conventional economic and political power. It is possible that they could grow into the role of a federation of world political parties and become a necessary counterweight to the transnational economy and the egoism of nation-states. The confrontation between a global enterprise, Shell Oil, and a transnational movement, Greenpeace, over the safe and environmentally sound disposal of the decommissioned North Sea oil platform Brent Spar, which escalated in 1995, is an example of the transformation of politics, and a sign of what is to come.

\section{SUMMARY AND CONCLUDING REMARKS}

As talk turns toward reevaluating the market as the solution for today's problems, market society needs to be reconstructed on a broader legitimating foundation - in order that the world can recover by means of it. Today, security policy that takes into account the common environment should also be incorporated within the framework of market logic, so that market efficiency in the end doesn't undermine the basis of life for all, including the most rational actors operating in conditions of perfect competition. Peace cannot be achieved without sharing. But no one gives up that to which $\mathrm{s} /$ he believes $\mathrm{s} /$ he alone is supposed to have a claim. A certain balance of initially unequal starting points is a demand for justice that is rooted in market justice, however. Equal opportunity as a central demand of market justice is also a demand for democratization; in this respect, throughout the world and especially in the core itself we have not reached the end of history. The aforementioned difficult relationship of market and politics should be regulated through an amalgamation of competition and cooperation. In our opinion, this coordination should facilitate the competition of state regulations and thereby produce, as is normally the case with innovations, pioneers, advantages, and thus incentives. Methods of unbridled competition must be prohibited through binding international social and ecological standards. Naturally, diverse egoistic interests are opposed to such a move.
In fairness, we must at the same time concede that our ideas about networking individual international regimes and embedding them in a global organization that would supervise them are not fully developed.

All the issues that we have addressed raise questions of constitutionality. The fact that these issues must be tackled in a global framework makes the task that much more difficult. However, in this century the world has already been confronted with a comparable challenge. Fifty years ago, the founding of the United Nations after World War II represented a new beginning and an improvement in comparison to the late Thirties and early Forties - although such is the way we always judge our successes in retrospect. Today, the reform of that world organization is on the agenda, and among the proposals is one to give more formal voice to critical actors in civil society. Informally, through their connection with innumerable organizations of transnational social and political movements, they already have exerted an influence at the global summits in Rio, Vienna, Cairo, Copenhagen, and Kyoto, a fact that signifies a change in world politics.

We conclude that civilization through today's hegemonic market society is not out of the question, but is obviously dependent on numerous prerequisites. Only after we have considered some of these prerequisites can we withdraw the question mark in the title of this essay, which stands for the challenges that must be overcome. In this way, the title becomes through praxis a program. 